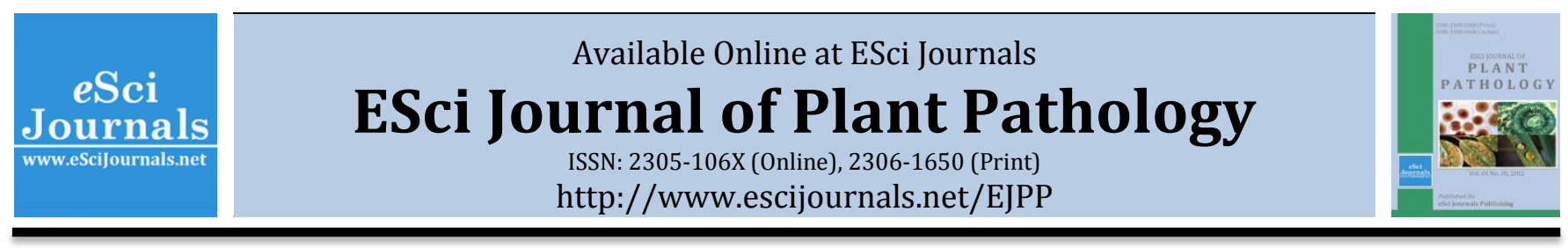

\title{
DEVELOPING CONTROL STRATEGIES OF POTATO WART DISEASE (SYNCHYTRIUM ENDOBIOTICUM) IN TURKEY
}

\author{
aHale Gunacti*, bAli Erkiliç \\ a Biological Control Research Station Directorare Kışla cad. Koprukoy Yüreğir, Adana, Turkey. \\ b Department of Plant Protection, Faculty of Agriculture, University of Cukurova, Adana, Turkey.
}

\section{A B S T R A C T}

The ultimate purpose of this study was to control Potato Wart Disease. Thus, during 2010 - 2011, in order to control the Potato Wart Disease caused by Synchytrium endobioticum the efficacy of seed fungicides and soil fumigants, the influence of 15 different plants used as alternative cropping to potato and the extracts derived from carrot, onion, garlic and radish were examined on the sporangium viability. The results revealed that the roots of turnip tuber were the most effective treatment among four different plant extracts used. Sunflower and Rye were found to be promising alternative crops to potato for the region with $74 \%$ and $73 \%$ of sporangium mortality, respectively. The most effective fumigant application on the viability of Synchytrium endobioticum sporangia in the soil was Formaldehyde with a 93.8 $97.5 \%$ efficacy rate. The fungicide efficacy on the diseases occurrence changed from $25.2 \%$ to $62.5 \%$ comparing to control plots. Although significant differences were obtained numerically between efficacy ratios, no statistically significant differences were found in all applications. The most effective application on Potato Wart Disease occurrence was the dosages of 60 and $80 \mathrm{~g} / \mathrm{m}^{2}$ of Metham Sodium among the four different concentrations of Formaldehyde, Metham Sodium, Dazomet and Urea as plant fertilizer.

Keywords: Synchytrium endobioticum, control, crop rotation, fumigant, plant extract, seed fungicide.

\section{INTRODUCTION}

Potato wart disease (PWD) is caused by the obligate soilborne fungus called Synchytrium endobioticum (Schilberszky). Percival belongs to Chytridiomycetes class (Langerfeld, 1984). PWD was transported from the And Mountains, South America to the North America and Europe at the end of 19th century. Nowadays, PWD is widespread in all potato growing regions of Asia, Africa, America and Pacific Ocean countries (EPPO, 2004). It was first detected in Turkey in Ordu (Aybasti), Nigde (Agcasar) and Nevsehir (Kaymakli, Derinkuyu) provinces in 2004 (Anonymous, 2009).

Typical symptoms of PWD are the cauliflower type warts on potato tubers. In early stages, the warts vary in sizes from the pea to the hand punch within white to green coloration (Hampson, 1981). PWD can cause symptoms in all parts of potato plants below the soil surface, except roots (Hampson and Haard, 1980). The main sources of

* Corresponding Author:

Email: hale_esen@hotmail.com

(C) 2013 ESci Journals Publishing. All rights reserved.
PWD spread are infected soil and infected plant materials (Hampson, 1995). The disease which usually prefers cool climates is currently known to exist in 43 countries (Baayen et al., 2006). The crop yield loss due to PWD varies between $50 \%$ and $100 \%$ of (Hampson, 1993; Melnik, 1998).

It has been reported that there is no chemical control the disease, yet. It is prevented with the application of strict quarantine measures, and it is essential that tuber and soil analyses be carried out to determine the fields infected with the disease. There is a zero tolerance disease. The field is considered to be infected in the incidence of even a single sport or a single diseased plant and potato farming is closed (EPPO, 1999).

Hampson and Coombes (1991) reported that the chemicals used for the eradication of pathogens that live in the soil for a long time are not preferred due to their phytotoxic and adverse environmental effects. Currently no practical method on control of the disease, but the growing resistant potato varieties is reported. PWD is also a very important disease which threatens not only 
potato growing areas but also all agricultural lands in the country. The presence of PWD, negatively affecting potato trade is listed as an external and domestic quarantine pest in Turkey.

The ultimate purpose of this study was to find out the efficacy of some applications to provide a basis for PWD control since there does not exist any control measure apart from quarantine legislations in Turkey. The study also aims to prevent the occurrence of the disease and to determine the opportunities to combat the disease with the chemical applications by identifying the factors that influence the zoospore secretion from sporangium.

In addition, the effects of some applications which could be the base of struggling against PWD having no applicable combat apart from quarantine measures were studied. The plant extracts applications which might cause by promoting and releasing the death of winter sporangium's zoospore were also tested since the plant extracts which can reduce the amount of inoculum in the soil and can be grown as an alternative to potato. Furthermore, the effects of chemicals on seeds and the effects of soil applications on the occurrence of the disease were investigated.

\section{MATERIALS AND METHODS}

The study design consisted of four trials to investigate the efficacy of seed fungicides and soil fumigants. The influence of 15 different plants used as alternative cropping to potato and the extracts derived from carrot, onion, garlic and radish were examined on the sporangium viability for the control of PWD caused by Synchytrium endobioticum. The results were compared to those of the control.

\section{Preparation of Synchytrium endobioticum Inoculum} and Compost Production: S. endobioticum inoculum and compost production were prepared using the fresh warts on potato tubers according to the method of Spieckermann and Kothoff, (1924). The warts were cut approx. $1 \mathrm{~cm}$. in size and added to sand by one portion of wart in three portions of sand (1W:3S). The mixture was incubated at $18-25^{\circ} \mathrm{C}$ in dark for six months and two replicates were conducted. The production of compost was completed in three steps: 1) one-third of the wart and the sand mixture in the clean trays were wetted with tap water and stirred every day during a period of two months. 2) wetting and stirring processes were carried out in weekly periods for two months 3) the compost was left to dry without any wetting and stirring process and kept at $+4^{\circ} \mathrm{C}$ for further use.
The Efficacy of Plant Cuttings on the Amount of Sporangium: In this section, the parts of the winter vegetables such as onion, garlic, carrot, radish and potato plant sprouts, inoculum density were determined, and applied to the infected soil.. The application was then examined to find out how the plant extract was affected by the release of sporangium zoospores.

Samples were assessed according to the method suggested by Zelya and Menlik (1998) to determine the amount of sporangium in Synchytrium endobioticum infested soil. Afterwards, $500 \mathrm{ml}$ glass bottles were filled up with $400 \mathrm{~g}$ soil and wetted with distilled water up to satisfied level. A total of $20 \mathrm{~g}$ obtained from potato shoots, green onion, green garlic, carrot and radish tubers with small cuts were added into each bottle and incubated in dark at $16^{\circ} \mathrm{C}$ for $3,6,9$ and 12 days intervals. Each character was repeated three times using randomized block design. Analysis of variance was applied to the data obtained, LSD multiple comparison test revealed the differences among the applications (Karman, 1971).

Efficacy of Alternative Plant Cultivation on the Amount of Sporangium: Fifteen cereals and winter crops alternative to potato were selected from the agricultural crops grown in the Turkish potato growing areas. The plants were Rye (Secale cereale), Sunflower (Helianthus annuus), Garlic (Allium sativum), Corn (Zea mays), Wheat (Triticum aestivum), Onion (Allium cepa), Alfalfa (Medicago sativa), Carrot (Daucus carota), Barley (Hordeum vulgare), Turnip (Raphanus sativus), Watermelon (Citrullus lanatus), Cauliflower (Brassica oleracea), Zucchini (Cucurbita pepo), Cabbage (Brassica oleracea), and Bean (Phaseolus vulgaris). Seeds from these fifteen crops were sown in pots with infected soil to test the capacity of their soil exudates to induce zoospore release from the sporangia in the soil. The initial density was determined as 35 sporangia/g soil. The pots were kept in the chambers provided with, $24^{\circ}$ $\mathrm{C}$ and $70 \%$ average humidity, $16 \mathrm{~h}$ light and $8 \mathrm{~h}$ darkness for 3 to 4 weeks then the amount of sporangium in the soil were counted (whether they are alive or not) to find out the sporangium death ratio and the efficacy of applications (Zelya and Menlik 1998). The experiment with four replications was set up on the randomly selected plots using randomized block design.

Effects of Seed Fungicide on PWD Occurrence: Fungicides from seven different active ingredients were used as seed treatment to observe the diseases 
occurrence. The names and active ingredients were, Metalaxyl (200g/L) Aprin, Metalaxyl$\mathrm{M}(40)+$ Acibenzolar-S-Methyl(\%4) Bion, Azoxystrobin(75 g/L)+Fludioxoni (12.5 g/L)+MetalaxylM (37.5 g/L) Dynasty, Thiabendazole (\%14) +İmazalil (\%10) Fruitgard, Fludioxonil (25g/L)+ Metalaxyl-M Maxim XL, Tebuconazole(60g/L) Raxil and Pomarsol Forte (\%80) Thiram. The study was conducted on infested soil in the pots $(25 \mathrm{~cm})$ in the open air. The pots were filled with the heavily infested soil obtained from the field with winter sporangium, and $150 \mathrm{~g}$ inoculum from the pathogen compost was prepared (Spieckermann and Kothoff, 1924). The seedling of Marfona variety known as to be sensitive to PWD was sown in each pot after fungicide application. The dipping method was used in the fungicides application. The experiment was a completely randomized parcel design with 5 replications. After 120 days, the plants were pulled out and the wart occurrences on tubers were evaluated according to 1-9 scale (EPPO, 2004). Disease severities were calculated according to the scale values, and analysis of variance was applied to these values. Then, the LSD multiple comparison test was administered to determine the differences among the applications of fungicide seed treatments and the effects of Abbott applications on $S$. endobioticum were determined (Karman, 1971).

The Soil Fumigants and Urea Effects on PWD Occurrence: The formaldehyde, metham sodium and dazomet as fumigants and also urea as plant fertilizer were used on PWD control in the study. Treatment dosages were 20, 40, 60 and $80 \mathrm{~g} / \mathrm{m} 2$ for dazomet, 20,
40, 60 and $80 \mathrm{ml} / \mathrm{m} 2$ for metham sodium, 100, 150, 200 and $250 \mathrm{ml} / \mathrm{m} 2$ for formaldehyde and 200, 400, 600 and $800 \mathrm{~g} / \mathrm{m} 2$ for urea respectively. The dosages converted to the pots sized $25 \mathrm{~cm}$ in diameter were applied. The pots were filled with heavily $S$. endobioticum infested soil obtained from Derinkuyu (Nevsehir province), $150 \mathrm{~g}$ of inoculum from the pathogen compost was prepared (Spieckermann and Kothoff, 1924) and the rest of pots were again filled with the infested soil. After watering the pots, they were covered with the polyethylene cover. After a week, the cover was removed for ventilation lasting two weeks. After the ventilation, half of the soil from each pot was transferred to new pots to saw Marfona seedling. The experiment with four replications was set up on the randomly selected plots.

After sowing, necessary maintenance and irrigation processes were performed periodically. After 120 days, the plants were pulled out and the wart occurrences on tubers were evaluated according to 1-9 scale (EPPO, 2004). Disease severities were calculated as mentioned above in (2.4).

\section{RESULTS}

The Efficacy of Plant Cuttings on the Amount of Sporangium: In this study, the effects of mixing the soil with the sprout of potato tuber, carrot-grassed radish tuber roots and leaf fragments diseased onion-garlic sporangium on the amount of sporangium were examined. The number of live sporangium, sporangium death rates and the effects rates of the applications in the soil samples examined at the end of the incubation were determined (Table 1).

Table 1. The Efficacy of Plant Cuttings on Winter Sporangia Viability of S. endobioticum.

\begin{tabular}{lcccccccc}
\hline \multirow{2}{*}{$\begin{array}{c}\text { Plant } \\
\text { Material }\end{array}$} & \multicolumn{2}{c}{ 3 Day } & \multicolumn{2}{c}{ 6 Day } & \multicolumn{2}{c}{ 9 Day } & \multicolumn{2}{c}{ 12 Day } \\
& $\begin{array}{c}\text { Mortality } \\
\text { ratio (\%) }\end{array}$ & $\begin{array}{c}\text { \% } \\
\text { Effect }\end{array}$ & $\begin{array}{c}\text { Mortality } \\
\text { ratio (\%) }\end{array}$ & \% Effect & $\begin{array}{c}\text { Mortality } \\
\text { ratio (\%) }\end{array}$ & \% Effect & $\begin{array}{c}\text { Mortality } \\
\text { ratio (\%) }\end{array}$ & \% Effect \\
\hline Carrot & $31.3 \mathrm{a}$ * & 30.4 & $31.3 \mathrm{a}$ & 25.8 & $30.7 \mathrm{~b}$ & 26.7 & $36.0 \mathrm{c}$ & 22.0 \\
Potato & $26.7 \mathrm{a}$ & 25.6 & $30.0 \mathrm{a}$ & 24.4 & $30.0 \mathrm{~b}$ & 26.0 & $48.7 \mathrm{bc}$ & 37.4 \\
Garlic & $40.0 \mathrm{a}$ & 39.1 & $34.0 \mathrm{a}$ & 28.7 & $41.3 \mathrm{ab}$ & 38.0 & $50.0 \mathrm{ab}$ & 39.0 \\
Onion & $30.0 \mathrm{a}$ & 29.0 & $24.0 \mathrm{ab}$ & 17.9 & $40.7 \mathrm{ab}$ & 37.3 & $48.0 \mathrm{bc}$ & 36.6 \\
Turnip & $30.0 \mathrm{a}$ & 29.0 & $38.7 \mathrm{a}$ & 33.7 & $55.3 \mathrm{a}$ & 52.9 & $63.3 \mathrm{a}$ & 55.4 \\
Control & $1.3 \mathrm{~b}$ & - & $7.3 \mathrm{~b}$ & - & $5.3 \mathrm{c}$ & - & $18.0 \mathrm{~d}$ & - \\
\hline
\end{tabular}

* Values with different letters are significantly different as LSD $(\mathrm{P}<0.05)$.

In the control plots, where the soil was just wetted, the sporangium level slightly decreased to 41.0 sporangium/g soil due to natural death. The sporangium death rate was different from those of the control plots in all applications; yet no statistical difference was detected. The sporangium death rate in onion cuts application was different from those of the control plot although the results were found to have similar 
statistical records on the 6th day. Soil applications consisting of radish, garlic and onion cuts on the 9th day, the sporangium death rate were recorded to be 55.3, 41.3 and $40.7 \%$, respectively, which were the highest sporangium death rate in all the experiments conducted in the study. On the 12th day, the radish application displayed the highest sporangium death rate resulted in $63.3 \%$, and followed with $50.0 \%$ with the garlic application. The applications of these experiments resulted in the remarkable death of zoospores released from the sporangia. The most effective application of the study was recorded in the radish tuber.

Alternative Plant Cultivation Efficacy on the Amount of Sporangium: This study was conducted under the assumption that the root exudates spread during the germination of some alternative plant seeds which could be grown in the potato cultivation ecology were likely to reduce the amount of sporangium. It was observed that the plants having a high capacity to keep the soil dry were more effective as compared to the others.

Furthermore, the sunflower and rye among 15 different alternative plants were found to be having the highest sporangium death rate with 76.4 and $75.7 \%$ respectively. The sporangium death rate varied from 31.4 to $62.9 \%$ on the other alternative plants (Table 2).

Table 2. Effects on Viability of Winter Sporangia of Alternative Plant Root Exudates

\begin{tabular}{lccc}
\hline \multicolumn{1}{c}{ Plants } & $\begin{array}{c}\text { Alive } \\
\text { sporangium } \\
\text { numbers }\end{array}$ & $\begin{array}{c}\text { Sporangia } \\
\text { mortality } \\
\text { ratio (\%) }\end{array}$ & $\begin{array}{c}\text { (\%) } \\
\text { Effect }\end{array}$ \\
\hline Rye & 8.5 & $75.7 \mathrm{a}$ * & 73.0 \\
Sunflower & 8.3 & $76.4 \mathrm{a}$ & 73.8 \\
Garlic & 13.0 & $62.9 \mathrm{ab}$ & 58.7 \\
Corn & 13,5 & $61.4 \mathrm{ab}$ & 57.1 \\
Wheat & 16.0 & $54.3 \mathrm{ab}$ & 49.2 \\
Onion & 18.3 & $47.9 \mathrm{ab}$ & 42.1 \\
Alfaalfa & 18.3 & $47.9 \mathrm{ab}$ & 42.1 \\
Carrot & 18.5 & $47.1 \mathrm{ab}$ & 41.3 \\
Barley & 19.8 & $43.6 \mathrm{a}-\mathrm{c}$ & 37.3 \\
Turnip & 19.8 & $43.6 \mathrm{a}-\mathrm{c}$ & 37.3 \\
Watermelon & 21.5 & $38.6 \mathrm{bc}$ & 31.7 \\
Cauliflower & 23.0 & $34.3 \mathrm{bc}$ & 27.0 \\
Zuccuni & 24.0 & $31.4 \mathrm{bc}$ & 23.8 \\
Cabbace & 24.0 & $31.4 \mathrm{bc}$ & 23.8 \\
Bean & 23.8 & $32.1 \mathrm{bc}$ & 24.6 \\
Control & 31.5 & $10.0 \mathrm{c}$ & - \\
\hline
\end{tabular}

* Values with different letters are significantly different as LSD $(\mathrm{P}<0.05)$.
The beginning population of 35 sporangium/g soil was given to the control wetted soil pots and the death rate from natural causes was found as $10 \%$.

The alternative plants efficacy varied from $23.8 \%$ to $73.8 \%$ according to the natural sporangium death in control pots (Table 2). Among the alternative plants of maize, garlic, wheat, onion and alfalfa, the death rate of sporangium was found as $50 \%$, and this rate was considered to be promising for future experiments. The rest of the vegetables, such as beans, zucchini, cauliflower and cabbage cultivated in Nigde and Nevsehir provinces showed lower efficacies with $25 \%$.

Effects of Seed Fungicide on the Diseases Occurrence: Among the disease occurrence and efficacy of seed fungicides in all applications conducted on the potato variety, Marfona always showed lower rate than those of the control plot in terms of the virulence (Table 3).

However, no statistically significant differences were found among the fungicides of Bion, Fruitgard, Maxim and Thiram. The most effective application (9.6\%) was obtained from Aprin (active ingredient; Metalaxyl). Apart from control plot and Maxim, the results of other fungicides were statistically close to the efficacy of Aprin (Table 3). The disease occurrence varied from $25.2 \%$ to $62.5 \%$ among the applications of fungicides when compared to those of the controls, yet no statistical differences occurred among all the applications.

Table 3. Effects on Disease Severity of S. endobioticum of Seed Fungicides.

\begin{tabular}{lcc}
\hline Fungicides & Diseases Severity (\%) & (\%) Effect \\
\hline Aprin & $9.6 \mathrm{a}^{*}$ & $62.5 \mathrm{a}$ \\
Bion & $16.9 \mathrm{a}-\mathrm{c}$ & $34.0 \mathrm{a}$ \\
Dynasty & $12.2 \mathrm{ab}$ & $52.2 \mathrm{a}$ \\
Fruitgard & $17.0 \mathrm{a}-\mathrm{c}$ & $33.4 \mathrm{a}$ \\
Maxim & $19.2 \mathrm{bc}$ & $25.1 \mathrm{a}$ \\
Raxil & $12.1 \mathrm{ab}$ & $52.8 \mathrm{a}$ \\
Thiram & $16.9 \mathrm{a}-\mathrm{c}$ & $34.0 \mathrm{a}$ \\
\hline Control & $25.6 \mathrm{c}$ & -
\end{tabular}

* Values with different letters are significantly different as $\operatorname{LSD}(\mathrm{P}<0.05)$.

The Soil Fumigants and Urea Effects on the Diseases Occurrence: In order to determine the disease occurrence, the fumigants applications and urea were studied. The disease severity and efficacy ratio were determined, accordingly (Table 4). 
The dosages of metham sodium at 60 and $80 \mathrm{~g} / \mathrm{m} 2$ were found to be the most effective. This was followed by $40 \mathrm{~g}$ of metham sodium (11.1\%), four dosages of formaldehyde (11.1-11.8\%), 200-600 $\mathrm{g}$ of urea (11.1$12 \%$ ) and $40 \mathrm{~g}$ of dazomet (11.7\%) dosages. The disease virulence was observed to be $8.3 \%$ in the application plot, as it was only $29 \%$ in the control. The highest disease virulence after control was recorded as $17.7 \%$ on the $60 \mathrm{~g}$ of dazomet dosage.

Table 4. Effects on Disease Severity of S. endobioticum of Soil Fumigants.

\begin{tabular}{|c|c|c|}
\hline $\begin{array}{l}\text { Application rates } \\
\left(\mathrm{g}-\mathrm{ml} / \mathrm{m}^{2}\right)\end{array}$ & $\begin{array}{c}\text { Diseases severity } \\
\text { (\%) }\end{array}$ & $\begin{array}{c}\text { (\%) } \\
\text { Effect }\end{array}$ \\
\hline Dazomet 20 & $12.7 \mathrm{a}-\mathrm{c}^{*}$ & $56.2 \mathrm{a}-\mathrm{c}$ \\
\hline Dazomet 40 & $11.7 \mathrm{ab}$ & $59.5 \mathrm{ab}$ \\
\hline Dazomet 60 & $17.7 \mathrm{c}$ & $38.7 \mathrm{c}$ \\
\hline Dazomet 80 & $15.4 \mathrm{bc}$ & $47.0 \mathrm{bc}$ \\
\hline Formaldehide 100 & $11.8 \mathrm{ab}$ & $59.0 \mathrm{ab}$ \\
\hline Formaldehide 150 & $11.1 \mathrm{ab}$ & $61.6 \mathrm{ab}$ \\
\hline Formaldehide 200 & $11.1 \mathrm{ab}$ & $61.6 \mathrm{ab}$ \\
\hline Formaldehide 250 & $11.1 \mathrm{ab}$ & $61.6 \mathrm{ab}$ \\
\hline Metham sodium 20 & $15.2 \mathrm{bc}$ & $46.5 \mathrm{bc}$ \\
\hline Metham sodium 40 & $11.1 \mathrm{ab}$ & $61.6 \mathrm{ab}$ \\
\hline Metham sodium 60 & $8.3 \mathrm{a}$ & $70.9 \mathrm{a}$ \\
\hline Metham sodium 80 & $8.3 \mathrm{a}$ & $70.9 \mathrm{a}$ \\
\hline Urea 200 & $11.1 \mathrm{ab}$ & $60.7 \mathrm{ab}$ \\
\hline Urea 400 & $11.9 \mathrm{ab}$ & $58.9 \mathrm{a}-\mathrm{c}$ \\
\hline Urea 600 & $12.0 \mathrm{ab}$ & $58.4 \mathrm{a}-\mathrm{c}$ \\
\hline Urea 800 & $14.0 \mathrm{bc}$ & $51.5 \mathrm{a}-\mathrm{c}$ \\
\hline Control & $29.0 \mathrm{~d}$ & - \\
\hline
\end{tabular}

* Values with different letters are significantly different as LSD $(\mathrm{P}<0.05)$.

\section{DISCUSSION}

In a study, to investigate the role of alternative plants and the impact of root exudates on sporangium amount were designate. In the present study, the interaction between the sporangium amount and root exudates released during the germination of seeds was taken into consideration. The highest sporangia death rate was obtained from the sunflower and rye among the 15 different plants alternative to potato cultivation. The crops such as cereals, maize, garlic, onion and alfalfa whit could keep the cultivation soil as dried in the areas infected with PWD were found to be significantly efficient on the rate of sporangia death (Gunacti and Erkilic, 2010).
Hampson (1979), demonstrated that leaving the diseases infected field to bare fallowing for 5 years subsequent to the cultivation of the tolerant variety, zucchini, maize, fava beans suppressed the PWD in Belarus. The same researcher suggested that leaving the infected field to fallow for about 3 to 5 years could result in $97 \%$ zoospore germination. The zoospore germination rate in this study increased up to $75 \%$ by using organic fertilizers derived from poultry, pig and cow.

The application of winter vegetable cut into the wetted soil in the areas where potato could be cultured resulted in the remarkable amount of zoospores released from sporangia following their death, and radish tuber application was found to be the most effective one out of 15 varieties of winter vegetables.

There have been many studies on the effects of plant extracts and composes on plant root and leaf pathogens. The results revealed that high percentages up to $100 \%$ were affected while some of the pathogens were either triggered or not affected (Thompson, 1986; Stind and Weltzien, 1988; Çakır and Yeğen, 1991). King and Smith (1968) maintained that the compound gained from the onion and garlic extracts would inhibit the sclerots of Sclerotinia cepivorum's and that the garlic extracts were better inhibitors than onion extracts. When the root and tuber extracts of such plants used in the study as radish, onion and garlic were blended in the contaminated soil, and then when the effects of this process on sporangium in the soil and the seeds of the same plants sown in the same soil were compared, it was observed that the plant extract applications were more effective than seed applications. This was assumed to have been resulted from the chemical compounds in plant extracts (Gunacti and Erkilic, 2010).

Systemic fungicides are reported to be the least effective ones against Oomycetes (Hampson, 1977). In this study, the fungicides were assumed to have a compound value in respect to PWD. In addition, Erwin (1973) stated that a difficulty with chemical control of PWD might lead to the infection court. Erwin also maintained that systemic fungicides could hardly effect the Oomycetes fungicides due to the difficulty to combat the disease with PWD in infected fields, yet some of the components seemed to be encouraging. Comparison between control and fungicides application and the diseases occurrence varied between 25.2 and $62.5 \%$. However, the efficacy rates of figures were different from each other, though 
there were no statistically significant differences between all applications.

In addition, with a zero tolerance of $S$. endobioticum, in gram soil even only one sporangium can cause infection (Hampson, 1993; EPPO, 2004). In the study of Hampson (1992), it was recorded that 0.25 sporangium in gram soil was able to initiate infection. However, the number of zoospore releasing sporangium was reported to be correlated more or less with the number of warts and their sizes, as well (Zakopal and Spitzova, 1959; Hampson, 1992; Browning 1995).

In another study, Hampson (1977) recorded 9 fungicides against the strain no. 2 of $S$. endobioticum used by dipping the tubers into the fungicide solutions, yet none of them were able to control the PWD in the field stage.

Up to date, among more than 400 experiments, no compound has been reported to control PWD, with high efficiency and adequate cost to apply in practice (Crowther et al., 1927; Gimingham, 1919; Hartman, 1955; Roach, 1925; Zakopal, 1950; Olsen, 1966; Kharitonova, 1969; Hampson, 1977; Hampson, 1993).

To check the efficacy of soil fumigants and urea on disease occurrence, a study was carried out. After testing the four different concentrations of each chemical, the most effective application was reported to be metham sodium in the dosages of 60 and $80 \mathrm{~g} / \mathrm{m} 2$ with $70.9 \%$ efficacy. In the control plot, a decrease up to $29 \%$ was observed on PWD virulence while it was only $8.3 \%$ in the application plot. Similarly increasing the fungicide dosages to the for tubers were resulted in no significant decrease on diseases virulence in this study. This result was associated with the behavior of the PWD sporangium and zoospore. The variance was, therefore, found to be quite high in the replicates of the experiments. This might have been resulted from two reasons; the distributions of pathogen sporangium's were homogeneous and the zoospore releases at different times (Stenz, 1963; Hampson, 1981; Hampson et al., 1994).

The results related with the soil fumigants efficacy on PWD obtained in this study are associated with those of the related studies. Potocek (1991) reported that the dosage of $100 \mathrm{ml} / \mathrm{m} 2$ metham sodium was successful in controlling the disease and dazomet at $60 \mathrm{gr} / \mathrm{m} 2$ dosage were also found effective. Although there hasn't been any current study on formaldehyde as a soil fumigant, Roach and Glynne (1928) highlighted the success of formaldehyde to control PWD. In addition, Reed and
Dickens (1993) suggested that the disinfection machinery, equipment by formaldehyde was the most effective way to prevent the disease spread.

Methyl bromide has been used in intensive agricultural land for soil disinfection for a long time. In some studies, methyl bromide has also been tested on S. endobioticum, which has resulted in success (Noehr and Mygind, 1977; Pearson et al., 2007). Similarly, chloropicrin, one of the active ingredients in methyl bromide, also has fungicidal impact as soil fumigant alone. Kharitonova (1969) tested and suggested it against PWD control.

Among the studies to control PWD by nitrogen fertilizers, urea and ammonium nitrate can be cited as the most studied ones. Potocek (1983), pointed out that the urea dosages of $1-1.5 \mathrm{~kg} / \mathrm{m} 2$ could be an effective disease control. However, in the current study, 200g dosage usage resulted in an efficacy rate of $60,7 \%$, which is promising. The differences on dosages and efficacy of nitrogen fertilizers reported in various studies might be resulted from the differences between the soil types and the strains of the pathogen (Hampson and Coombes, 1996). The differentiations among the results obtained in previous experiments might be associated with the presence of 43 strains of $S$. endobioticum (Baayen et al., 2006). The efficacy of urea on pathogen control was not achieved because of its chemical structure. It was determined according to the result of the $\mathrm{pH}$ changes in the soil (Weiss, 1925; McLaren and Peterson 1967; Hampson, 1980). Weiss (1925) reported that infection by pathogen could occur at a pH level of 3.9-8.5. Furthermore, Zakopal and Spitzova (1959) suggested that PWD could be developed at a pH level of 2.5-12.38. The optimum growth of the pathogen for infection was also considered between the pH levels of 6-8. However, these results conflict with the results of Hampson (1985) on the mode of urea action. Hampson (1985) claimed that the impact of urea in the soil $\mathrm{pH}$ level has an important on the efficacy of diseases occurrence that was claimed because of acidic character of urea with a decreasing affect in the soil $\mathrm{pH}$ level. The soil $\mathrm{pH}$ values of this study were between $7.55-7,58$. To control PWD, it is not feasible to decrease the soil $\mathrm{pH}$ below 2.5 and 3.9 which triggers the pathogen infection by applying high amount of urea. In addition, using a high amount of urea to combat disease is not likely to reduce the soil $\mathrm{pH}$ below 2.5-3.9 levels which initiates pathogen infection.

Even if it was achieved, it would be too acidic to cultivate 
potato crop under the indicated $\mathrm{pH}$, hence, more detailed studies should be carried out on the $\mathrm{pH}$ intervals for pathogen infections and mechanism of urea action on disease occurrence in order to reveal much more reliable results. In such situations, urea and other similar chemicals naturally could show different effects in different soil textures.

In conclusion, considering the characteristic feature of the disease, and the zero tolerance of the pathogen in soil, we maintain that any practice alone to control PWD is not sufficient. Removal of the soil and tuber should be strictly avoided. Two major problems could be encountered in chemical control of PWD; the chemicals cited as effective against PWD pose a threat to human, animal and plant health and controlling the disease with the application of integrated product management is limited. Therefore, the main principle in PWD control should be achieved only by applying strict quarantine measures to prevent the disease spread.

\section{REFERENCES}

Anonymous, 2009. Nevsehir Provincial Directorate of Agriculture data reported Wart disease 19- 25 November 2009.

Baayen, R.P., G. Cochius, H. Hendriks, J.P. Meffert, J. Bakker and M. Bekker. 2006. History of potato wart disease in Europe a propasol for harmonisation in defining pathotypes. European Journal of Plant Pathol. 116: 21-31.

Browning, I.A. 1995. A comparison of laboratory and field reactions of a range of potato cultivars to infection with Synchytrium endobioticum. Potato Res. 38: 281-289.

Çakir, C and O. Yeğen. 1991. Antalya and surrounding investigation of potential fungitoksik some plants and essential oils. VI. Phytopathol. Cong. of Turkey. 213-218.

Crowter, E.M., M.D. Glynne and W. A. Roach. 1927. Sulphur treatment of soil and the control of wart disease of potatoes in pot experiments. Ann. Appl. Biol. 14: 422-427.

EPPO 1999. EPPO Standards PM 3/59. Synchytrium endobioticum: soil tests and descheduling of previously infested plots. bulletin OEPP/EPPO Bull. 29: 225-231.

EPPO 2004. Diagnostic Protocols for Regulated Pests: Synchytrium endobioticum. 34. (2): 213-218.
Erwin, D.C. 1973. Systemic fungicides: disease control, translocation, and mode of action.Ann. Rev. of Phytopathol, 11: 389-422.

Gimingham, C.R. and G.T. Spinks. 1919. Soil sterilization. Univ. Bristol Agr. Hort. Res. Sta. Annu. Rep.

Glynne, M.D. 1928. Infection experiments with wart disease of potato Synchytrium endobioticum. Ann. of Appl. Biol, 12: 24-60.

Gunacti, H. and A. Erkilic. 2010. Research on potato wart disease Synchytrium endobioticum (Schilb.) Perc. biology, disease epidemiology and control methods. PhD ths. Cukurova University, Adana, Turkey.

Hampson, M.C. 1977. Screening systemic fungicides for potato wart disease. Can. Plant Dis. Surv. 57: 7578.

Hampson, M.C. 1979. Infection of additional hosts of Synchytrium endobioticum, the causal agent of potato wart disease: 2. tomato, tobacco and species of Capsicastrum, Datura, Physalis and Schizanthus. Can. Plant Dis. Surv. 59: 3-6.

Hampson, M.C. 1980. Pathogenesis of Synchytrium endobioticum: 2. effects of soil amendments and fertilization. Can. J. Plant Pathol. 20: 148-151.

Hampson, M.C. 1981. Potato sprouts and potato wart disease. Can. Agric. 26(3): 30-31.

Hampson, M.C. 1985. Pathogenesis of Synchytrium endobioticum: V. wart disease suppression in potato in soils amended with urea and/or ammonium nitrate in relation to soil $\mathrm{pH}$. Plant Soil, 87: 241-250.

Hampson, M.C. 1992. A Bioassay for Synchytrium endobioticum Using Micropropaged Potato Plantles. Can. J. Plant Pathol. 14: 289-292.

Hampson M.C. 1993. History, biology and control of potato wart disease in Canada. Can. J. Plant Pathol. 15: 223-244.

Hampson M.C., J.W. Coombes and K.B. McRAE. 1994. Pathogenesis of Synchytrium endobioticum: VIII. effect of temperature and resting spore density (rrk2) on incidense of potato wart disease. Can. J. of Plant Pathol. 16: 195-198.

Hampson, M.C. 1995. Wart disease of potato caused by Synchytrium endobioticum. Plant Dis. 79: 649.

Hampson, M.C. and N.F. Haard. 1980. Pathogenesis of Synchytrium endobioticum: 1. infection responses in potato and tomato. Can. J. Plant Pathol. 2: 143147. 
Hampson, M.C. and J.W. Coombes. 1991. Pathogenesis of Synchytrium endobioticum: IX. effect of irrigation regimes and soil mixes on disease incidence with pathotype 2. Can.J. Plant Pathol. 19: 47-51.

Hampson, M.C. and J.W. Coombes. (1996). Spatial distribution of Synchytrium endobioticum, the cause of potato wart disease, in field soil. Plant.Dis. 80: 1006-1010.

Hartman, R.E. 1955. Potato wart eradication program in Pensilvania. Am. Potato J. 32: 317-326.

Karman, M. 1971. Plant protection research general information. principles of organisation and evaluation trials. Agri. Research Inst. Bornova Izmir, Turkey.

Kharitonova, Z.M. 1969. Research on potato wart disease in U.S.S.R. a literature review (1955-1977). Can. Plant Dis. Surv. 59(1): 7-14.

King, B.E. and J.R. Coley-Smith. 1968. Effects of volatile products of Allium species and their extracts on germination of Sclerotia cepivorum. Ann. Appl. Biol.6 (1): 407-411.

Langerfeld, E. 1984. Synchytrium endobioticum (Schilb.) Perc. zusammenfassende darstellung des erregers des kartoffelkrebses anhand von literaturberichten. Mitt Biol Bundesanst LandForstwirtsch Berl-Dahl 219: 1-142, (in German).

Mclaren, A.D. and G.H. Peterson. 1967. Soil biochemistry. M Dekker Inc., New York. P: 509.

Melnik, P.A. 1998. Wart disease of potato, Synchytrium endobioticum (Schilb.) Perc.. EPPO technical documents no. 1032, EPPO, Paris (FR).

Noehr, R. and H. Mygind. 1977. Control of potato wart disease (Synchytrium endobioticum) though Methyl Bromide soil disinfection. Tidsskrift for Planteavl. 81: 25-31.

Olsen, O.A. 1966. Control of potato wart by chemical treatments. Can. Plant Dis. Surv. 46: 1-4.

Pearson, H.G., M. Braithwaite. and I. Veljkovic. 2007. New Zealand plant protection society www.nzpps.org.

Potocek, J. 1983. Quantitative determination of resting zoosporangia of the causative agent of potato wart in soil samples and control sbor. UVTIZ-Ochr. Rostl. 13: 251-252.
Potocek, J. 1991. Sanitation of soil infested with Synchytrium endobioticum. Plant Dis. 27: 265272.

Reed, P.J. and J.S.W. Dickens. 1993. Evaluation of various disinfectants aganist potato wart disease test of agrochemicals and cultivars 14 Ann Appl. Biol. 122.

Roach, W.A., M. Glynne., W.B. Brierley and E.M. Crowther. 1925. Experiments on the control of wart disease of potatoes by soil treatment with particular reference to the use sulphur. Ann. Appl. Biol. 12: 152-190.

Spieckermann, A. and P. Kothoff. 1924. Testing potatoes for wart resistance. Deutsche Landwirtschaftliche Presse. 51: 114-115.

Stenz, G. 1963. Beitrage zur ökologie des kartoffelkrebserregers (Synchytrium endobioticum (Schilb.) Perc.). Nachricht. Deutsch. Pflanzenschutz. 17: 116-123.

Stind, A. and H.C. Weltzien. 1988. Application of extracts of composed organic material for the control of Botrytis cinerea on strawberies. Gesude Pflanzen 40 Jahrg. Heft. 11: 451-454.

Thompson, D.P. 1986. Effects of essential oils on spore germination of Rhizopus sp, Mucor and Aspergillus species. Myco, 78(3): 482485.

Weiss, F.A. 1925. The conditions of infection in potato wart. Am. J. of Bot., 12 (7): 413-443.

Zakopal, J. 1950. The possibility of soil disinfection against potato wart disease (Synchytrium endobioticum (Schilb.) Perc.) with a preparation containing 2, 4 dinitro-orthocresol (in Czechoslovak, English summary). Sb. Cesk. Akad. Zemed. Ved. 23(1/2): 132-141.

Zakopal, J. and B. Spitzova. 1959. The effect of temperature on the development of infection with summer zoospores of potato wart disease. Plant Prot. 5 (6): 60-67.

Zelya, A.G. and P.A. Melnik. 1998. detections methods for Synchytrium endobioticum. Bulletin EPPO/EPPO Bull. 28: 543-544. 